$\xi=-1$ 圆

\title{
The quest for environmental sustainability in educational institutions
}

\author{
Nand Kumar', Ashwani Kumar', Sunil Sharma ${ }^{2}$ \\ ${ }^{1}$ Assistant Professor, Department of Architecture and Planning, M.N.I.T. Jaipur \\ ${ }^{2}$ Ph.D. scholar, Department of Architecture and Planning, M.N.I.T. Jaipur \\ *Corresponding author E-mail: akumar.arch@mnit.ac.in; 2016rar9060@mnit.ac.in
}

\begin{abstract}
Over the last four decades "Sustainable Development" has emerged as a catchphrase while defining development. Many reforms have taken up in the past to solve ever-increasing snags related to untenable development at local as well as global level. However, the review of literature pertaining to sustainable development shows that it lacks in proper interpretation and consistency in the definition across the globe. Further, it's the environmental sustainability aspect that has been compromised again and again to give way to economic development. In practice, environmental sustainability is not considered as equally significant in comparison to the other two aspects of sustainability. The issues of sustainability in educational institutions have historical pedigree starting from Stockholm Declaration, Tbilisi Declarations and subsequently a lot of evolution has taken place in this field. Still, most of the educational institutions lack their roadmap to attain sustainable development. Some of the universities have tried to implement their own sustainability plan apart from signing any major declaration. This review paper suggests that environmental sustainability is the need of the hour and this concept need more workable, elaborated and practical solution which need to be free from political bias and possess intellectual clarity and objectivity.
\end{abstract}

Keywords: Educational Institutions; Environmental Sustainability; Stockholm Declaration; Sustainability; Sustainable Development

\section{Introduction}

Over the last few decades, unsustainable growth had occurred in built environment mainly due to evolving and implementing unscientific plans coupled with inappropriate land uses, faulty projections, etc. This growth leads to deterioration of the built environment, and we are facing severe global challenges, i.e., global warming, GHG emissions, loss of biodiversity, etc. Many reforms have taken up in the past to solve these ever-increasing snags, but most of the time it's the environmental sustainability aspect that has been compromised again and again to give way to economic development. Environmental sustainability is not considered equally significant in comparison to the other two issues of sustainability. Moreover, According to Samir and Lutz [1], India is set to become the most populous country by 2025 overturning China and Drezer [2] stated that India is the fourth largest economy in the world; hence, energy consumption in India is most likely to increase significantly. This increased power consumption will further enhance the dependency on conventional fossil fuel which eventually leads not only to the shortage of fossil fuels but also causes its ill effects in the form of GHG emission and fuel poverty.

A comprehensive policy is needed for making built environment environmentally sustainable with emphasis should be on providing environmentally sustainable solutions to various land-uses within a city such as residential areas, commercial stretches, industrial area, institutional areas, etc. Educational campuses within institutional land use are one of the most neglected areas for studies related to sustainable development and its related issues. For example, the energy conservation is not considered as equally important in educational campuses than other major land uses owing to their low per capita electricity consumption. On the contrary, many international declarations like Tbilisi declaration have stressed on the sustainable development related issues of the educational institutions. It has been significantly highlighted in Talloires declaration that universities and educational institutions can act as role model for sustainable development of the surrounding community [3]. This review paper tries to provide the literature based on various declarations that have taken place in the field of environmental sustainability issue mainly dealing with environmental problems and also look into multiple sustainability initiatives undertaken by different universities.

\section{Sustainability and Sustainable Develop- ment}

In ancient India, sustainability was linked with lifestyle. The three attributes namely Aparigraha (minimum possession), conservation (minimum consumption) and recycling (minimum waste) constitutes the Indian way of life and are the guiding principles for the buildings as well. The ancient Vedic and post-Vedic Sanskrit literature presents in great detail about environmental protection, ecological balance, water use and management, hydrology, weather cycle, rainfall phenomenon, and related aspects [4]. It's vital that the building should reciprocate with its surrounding. Preferably a building should symbiotically fit within prevalent natural cycles. Further as described by Rana [5] that we must realize that the earth is the only habitable place that we have and its resources are limited. Energy efficiency and water management act as two major approaches to attain environmental sustainability. The approach to sustainability leads to sustainable development. 
It's important to know the dictionary meaning of sustainable development before looking into the depth of the concept $[6,7]$. The dictionary meaning of 'develop' is "Grow or cause to grow and become more mature." Further development specifies movement towards achieving a goal such as meeting out the basic requirement, attaining welfare of society regarding economic, social, spiritual aspects. Sustainable means ability to maintain at a certain rate or level [8]. At a broader level, it is to maintain a community, establishment, etc. at the proper level to keep from falling [9]. There exists a wide number of definitions for Sustainable development, and some are very vague. Some researchers believe that economic growth is sustainable development. Some scholars argue that sustainability is not a thing to be declared but is an ethical principle [10]. Despite the differences in definitions, Brooks [11] claims that its necessary to derive the operational definition of sustainable development which must inform about alternate strategies, technologies, and systems for long-term sustainability. The definition must include objectives, principles, issues, etc. There should be no delay in the decisions related to investment and relevant policy related to sustainable development, failing which world will have to face the consequences in the future, many of which may be physically or economically unsustainable and irreversible [12]. "Sustainable development" is a 'meta fix' that will unite various stakeholders together like an entrepreneur, policymakers, politicians, bureaucrat, farmers, technicians, architects, etc. [13].

The most acceptable definition of sustainable development highlighted in Brundtland Commission Report in the year 1987. It states that sustainable development is a type of development which requires fulfillment of needs and wants of the contemporary generation without compromising the competency of future generations to meet their own needs. It focuses on two key concepts: The concept of 'needs' and the 'limitation' imposed. 'Needs' in particular, give priority to the essential requirement of the world's poor whereas the idea of 'limitation' deals with the ability of the environment to meet present and future needs. This concept can be imposed by the competent authority such as the state of technology and social organization [14].

This definition underlines the importance of ensuring that the lifesupport system of the planet and the land including soil fertility, together with the essentials ecological functions performed by the living organisms should be maintained. This definition also implies that the assimilative capacity of a receiving environment should not be exceeded and that all life on the planet should be respected. So the definition environmental/ecological problems are well documented, and many ecological economists are now concerned to ensure that the resources (renewable, non-renewable, and environment services) are given due recognition and included in any study of the contemporary economic situation $[15,16]$. Following this definitions researchers and academicians tried to develop the comprehensive working definition using three pillars of sustainability namely environmental, social and economic sustainability. So, it is after the Brundtland Commission report; the world realized the importance of attaining environmental problems. Failing which, it will lead to disaster at a global level which can endanger not only the natural habitat but also humans as a species as well. Further, in the last few decades, environmental sustainability was addressed at many declarations and conferences, etc. like Kyoto Protocol, Geneva Convention, Rio earth-summit and many others.

\subsection{Environmental Sustainability}

According to Rana environment of the species is the final analysis of everything (physical, chemical, biological) present outside that individual species [5]. So protection of the environment is a must for the survival of that species. It's true for a human being as well, being a biological species. Looking at the present situation of environment degradation environmental sustainability has become the need of the hour and is also highlighted in many of the United Nation's conferences held in the past. Though sustainability was defined in Brundtland commission, report the definition was broad and many academicians, scientists, etc., have tried to evolve a more working definition which can be used for practical purpose. Goodland R [17] sought to define environmental sustainability as means natural capital must be maintained, both as a provider of inputs ("sources") and as a "sink" for wastes. This means keeping the scale of the human economic subsystem to within the biophysical limits of the overall ecosystem on which it depends. The definition of environmental sustainability as the "maintenance of natural capital" constitutes the input-output rules. Here the output is the waste emission should be within the assimilative capacity of the local environment and input implies "harvest renewable" resources to its regeneration rate and non-renewable should be precisely used as such rate that it is replaceable by renewables in sufficient time.

To compute sustainable development many green rating systems have developed by various countries and organizations like GB Tool, LEED, CASBEE, USGBC, IGBC, GRIHA, etc., which also tried to quantify environmental sustainability aspect of sustainability. Most of these tools take energy consumption, water consumption and their utilization factor as a quantitative entity to measure its effect on the environment. So, in turn, they act as one of the major indicators to quantify environmental suitability.

\subsection{Problems About Environmental Sustainability}

Environmental problems come when the need becomes greed, and the basic requirement of human being becomes higher than the regeneration limit of the resources. Today global warming, pollution level in the air, water and soil is increasing at an alarming rate are the major challenges and problems for environmental sustainability. A major part of air pollution is generated through power generation provided to the cities. So it's the energy, it is harnessed and used sustainably, can solve much of the problem. In last few decades energy consumption has also increased manifolds attributed to a sharp growth in demand for electricity from various sectors, especially the construction industry. The buildings are responsible for at least 40 percent of the total energy requirement across the globe [18]. Hence, the construction industry is one of the leading areas involved in total carbon emissions in the environment and plays a significant role in the energy dynamics of the region.

The use of electricity depends on various factors like building use, personal preferences, appliances availability in the area, type of equipment used, access to latest technology, etc. this is also a function of population and level of development. The OECD countries in the United States have high consumption compared to OECD countries of Europe and Asia [19]. This implies a positive correlation between economic growth and energy consumption. This argument is supported the empirical results got by Lee C.C. \& Chang C.P. [20] which fully support a positive long-run cointegrated relationship between real GDP and energy consumption when the heterogeneous country effect is taken into account. Emphatically the adverse effect of deterioration of environment can be seen as in the form of pollution, loss of biodiversity, erratic behavior of climate, etc., which can lead to possible disaster. As far as educational institutions are considered, assessing the ecological footprint may help in mitigating problems related to environmental sustainability [21].

\subsection{Environmental Sustainability in Educational Insti- tutions}

Educational institutions just don't have the responsibility to educate the young generation but also have added the responsibility of educating youth about sustainability and also the dissemination of knowledge/skill/technology to the surrounding community for sustainable development. Today higher education sector has witnessed a remarkable increase in the number of universities/university level Institutions \& colleges. The aggregate number of universities has grown more than 30 times from 20 in 
1950 to 677 in 2014 and includes 45 Central Universities (12 new enacted in 2009), 318 State level Universities, 185 State universities (Private), 129 Deemed to be Universities and also includes 51 institutions of national importance. The number of colleges has also recorded manifold increase with just 500 in 1950 growing to 37,204, as on 31st March 2013 [22]. So with the growth in population and educations penetration, these sectors have grown phenomenally.

Looking at this trend and current scenario most of the old universities campuses are in the process of redevelopment stage to accommodate future growth. This has stressed the existing infrastructure including water management, contract demand of electricity, etc., leading to increasing per capita electrical and water consumption and other resources which have a direct and indirect effect on the environment. This has also affected the problem-related to biodiversity. Today most of the universities do not have a dedicated environmental cell and proper environmental development plan due to lack of awareness and will.

So, looking at the current trend and scenario of next $10-15$ years India will face a critical challenge of providing sustainable educational campuses. Meeting out this challenge is critical as it may act as a catalyst for the development of not only university campuses but also surrounding communities and universities can act as a role model of development.

In the last three decades, many declarations and conferences held to address the issue related to sustainable development, sustainable education and suitability in education institutions Given below is a summary of major international and national declarations held in the last few decades related to environmental sustainability in higher education and sustainable development of educational Institutes.

\subsubsection{Stockholm Declaration (1972)}

There is no direct mention of universities in Stockholm declaration, but principle offered in this declaration has relevance. It states the interdependence of humanity and environment. It is the first document to discuss intra and inter-generational equity amongst human. It includes 24 principles in all and also includes principles related to sustainability. Specifically, the $19^{\text {th }}$ Principle stresses the need for environmental education at every level of education from grade school to college to adulthood. The motive behind this was that the education would "broaden the basis for enlightened opinion and responsible conduct of individuals, enterprise, and communities in protecting and improving the environment in its full human dimension" [23].

\subsubsection{Tbilisi Declaration}

This declaration states that environmental education should be provided to persons of all age groups, to students at the different level of education and must be conveyed in both formal and nonformal ways. This declaration This declaration asked higher education to ponder environmental sustainability issues within the agenda of the university [24].

\subsubsection{Talloires Declaration}

This declaration encourages all universities to move towards sustainable future by taking steps related to the education of people, development of research and policy framework, and information exchange on population, environment, and development among signatories of this declaration. There were 20 signatories in 1990 which increased up to 275 in 2000 . Some of the signatories include University of Brighton, Delhi University, Osmania University, Colegio de Mexico, University of Pittsburg, and the University of Witwatersrand- Union of South Africa, etc. For review purpose Romero categories participating universities into following categories:

Category-I: Universities which have not attempted to follow the declaration; Category-II: Universities which are attempting to implement the declaration within their institutions: Ball states University in Muncie, Indiana, USA, etc., are some examples. Category-III: Have incorporated the umbrella principle of declaration and attempting to implement it.

\subsubsection{Halifax Declaration (1991)}

This declaration was held in Halifax, Canada in 1991. It emphasized on outlining the short and long-term goals for Canadian universities to achieve sustainable development and to identify a specific framework for action to implement it. Wright [24] has found that the most of the signatory universities have failed to implement the declaration. Many Universities tried to implement general concepts as measures to achieve sustainability but were uncertain about applying the declaration as the main policy for development. The University of British Colombia acknowledged Halifax Declaration but created its own institutional policy based on Halifax and Talloires declarations.

Dalhousie University created new environmental policy replacing the earlier policies showing their commitment related to the signing of major declarations like Talloires declaration, the Halifax Declaration and the international declaration on cleaner production. many Universities echoed their support for Halifax declaration but refrained from implementing it. The primary reasons were given by Wright [24] that the declaration was not as successful as thought were lack of leadership/accountability and monetary constraints among universities.

\subsubsection{Rio Earth Summit (Agenda 21)}

This Summit was one of the main milestone in the field of sustainable development, held in Rio de Janeiro in 1992. The fundamental sustainability principles for the summit was taken from Tbilisi Declaration and are listed in the agenda 21. The three most important thrusts of Agenda-21 were, reorienting education towards sustainable development, increasing public awareness of environmental issues and promoting environmental training among educators. Chapter 36 of this summit mentions that individuals, governments, and nations will have to ensure sustainable development. The Chapter 36 acknowledged lack of environmental awareness across the globe and recognized formal and informal education as one of the primary solutions to unsustainable behavior related to the environment. It was also recognized that each country is different in their social, economic and other aspects and it's also significant to look at their specific needs, policies and responsibilities while addressing sustainable development.

\subsubsection{Kyoto Declaration}

Kyoto Declaration was closely related to agenda 21 held in Kyoto, Japan in 1991 and around ninety leaders took participation in this ninth international association of universities round table conference. In this declarations, it was stressed that the international university community must create specific plans of action to pursue the goals of sustainability. An important feature of the declaration was to engage universities in working for achieving sustainability in physical operations in their respective campuses along with implementing environmental education. There are no signatories. Kyoto declaration was endorsed by IAU (All International Association of Universities). IAU Members and the general conference members had met in South Africa. The text of endorsed declaration- (IAU policy work plan 2000-2004) degree at which IAU universities have initiated recommendation of the declaration and work plan to date is unknown $[24,25]$.

\subsubsection{Swansea declaration:}

In this declaration, 400 universities of 47 countries echoed the sentiments of the past declarations held at Swansea, Wales, in 1993. Again this declaration proclaimed that universities had a 
major responsibility to help societies develop in an "environmentally secure and civilized world" (UNESCO, 1993 p.1). These include a review of physical operation in universities. This declaration also emphasized on creating environmentally literate students and faculty members and gave stress on the moral responsibilities of the universities to guide present and future generations. Swansea declaration stressed equality among different countries as the primary factor in attaining sustainable development.

\subsubsection{Copernicus Charter - (The University Charter for Sustainable Development)}

Association of European Universities developed the Copernicus Charter. This charter also stressed on the need for universities to take the initiative for creating sustainable societies and encouraging higher education community to adopt environmental values. 500 universities of 36 countries are part of this charter. Further Copernicus charter emphasized the need for networking among universities. Goteborg University (Sweden) present a success story of the charter had signed it in 1994 and subsequently created the plan and implemented it based on the tenets of the charter. There plan covers six main goals related to minimizing the environmental harm from the campus, physical operations, etc.

\subsubsection{Thessaloniki declaration}

Thessaloniki conference held in Greece in 1997 at the UNESCO conference on environment and Society. This declaration emphasized that sustainability initiatives should follow interdisciplinary nature and should be followed by different strata of society. The focus should be on intertwining to systems like democracy, population, culture health and peace and their subsystems. This declaration also focused on reorienting universities towards a holistic approach to be incorporated in education. However many signatories universities and institutions of higher education failed to live up to the charter expectations. Walton [26] claimed that certifying a declaration is no longer satisfactory

\subsection{Sustainability initiatives by Universities}

Many Universities have devised their sustainability evaluation criteria systems while some of them are following national/international declarations. Wright [24] presented the list of some of the Universities which have developed their own sustainability criteria's are as under:

\subsubsection{University of Waterloo}

This university had its environmental policy and refrained from signing any of the declaration. It has one of the most sophisticated and implemented policies with encouraging results related to sustainability in higher education areas [24,27]. WAT green committee is formed to look after the sustainability initiatives and is fully operational and is responsible for making this university flag barrier the field of sustainability. It has been very successful in being a leader in sustainability initiative both within the university and surrounding community.

\subsubsection{University of South Carolina}

This university takes the initiative in the form of creating institute specific environmental policy and has not signed any declaration, though USC is a part of South Carolina sustainable universities initiative.

\subsubsection{University of Buffalo}

The University of Buffalo had signed Talloires declaration in 1999. Many of its environmental policies of the university were well established before becoming a signatory to the declaration. This university has multiple policies relevant to environmental sustainability. The environmental task force (ETF) in 1990 created to look after the matter regarding campus environmental policies. 15 policies related to environmental sustainability designed to make campus biologically rich and less energy intensive.

\subsubsection{University of Toronto}

The University of Toronto gave special emphasis to physical operations as a part of sustainability initiative which includes minimization of energy use, water use, waste generation and pollution.

\subsubsection{George Washington University:}

This University has tried to initiate sustainable development by creating its institutional environmental policy but have also signed Talloires declaration. Further, Univerity is creating a model of sustainable development along with United States environmental protection agency (EPA). The University offers principles related to preservation of ecosystem, environment management, pollution prevention, etc. These principles guide university authorities to take better decisions by environmental management and posses accountability of university operations and functions.

\subsection{Sustainability initiatives by Indian Universities}

the Indian universities like Delhi University, Osmania University, have signed international declarations, but most of them have not implemented it properly. The Indian Institute of Technology Delhi (IIT Delhi) has decided to take environment- friendly initiative by taking measures related to biodiversity, energy, water conservation and minimizing waste by the guidelines given by concerned ministry to reduce carbon footprint. To mitigate these functions, IIT Delhi has constituted a dedicated office namely "Green Office." The main purpose of this office is to "track, monitor and guide the Institute towards green and sustainable practices." The Central University of Rajasthan has come up with rainwater harvesting ponds along the eastern and southern periphery of the campus is a remarkable initiative taken concerning environmental sustainability. The under-construction campuses of IIT Jodhpur and IIM Udaipur also represents the initiative taken to preserve the environment to reduce carbon footprint.

It is important to have a clear vision of how declaration can become implemented effectively at Institution level, rather than reporting on best practice cases. To adopt it or to take it as guidance is the choice of the university. It is also imperative to acknowledge failure and build on lessons learned. Further exploration is needed that it is just for the public relation of can truly affect the change.

\subsection{Green Building Rating Systems and Sustainability}

A green building rating system is an assessment tool that measures the environmental performance of a building/campus through its life cycle by a set of criteria covering various parameters such as parameters related to building/campus design, construction and maintenance and operation of a green building" (GRIHA Manual Vol-1). Many countries felt the need of developing green building rating system after the Brundtland Commission report stressed about sustainable development. Most of the Indicators of these rating systems are based on various aspects representing all the three pillars of sustainability have evolved in due course of time across the world to address the sustainable development through implementing green technology/ interventions in the building section. Ecological footprints as a measure of sustainability were proposed and developed by Rees and Wackernagel [28]. BREEM is the oldest rating system initiated in 1990. Subsequently, many 
other rating systems evolved after that namely GB Tool in 1998, LEED in 1998, CASBEE in 2001, green globes U.S. in 2004, IGBC 2001, GRIHA in 2007, etc.

Applicability, development, usability, System maturity, technical content, Measurability, and verification, communicability, etc. are criteria's that contribute to the credibility of the rating system. Cole stressed that it is important to know the methodology behind the rating system and what type of goals that have achieved while doing the auditing. He also emphasized that measurements of environmental impacts, development and ownership by authentic organizations, and having a proven track record of success, etc., should be included in reliability considerations for sustainable building rating systems [29]. Optimizing energy use is one of the most important criteria in most of the rating systems, and its weight-age is around 20-30 percent range. In India, GRIHA Rating was developed by TERI and MNRE to rate buildings located in India. This rating system depends on the size of a project like for smaller project SVA GRIHA is used, for middlesized projects GRIHA Rating (GRIHA V 2015) is used, and for larger campuses, GRIHA Rating for Large Area Development is used.

\section{Discussion}

It is clear that sustainable development is the need of the hour. Brundtland commission interpretation of sustainable development based on two key concepts generate curiosity amongst various stakeholders of society for finding the more working definition of sustainability that can be implemented in a real-world scenario. It is also evident that environmental sustainability is ignored as compared to other two pillars of sustainability namely economic and social sustainability. As building industry is responsible for more than 40 percent of the total energy consumption, so it becomes imperative to look in this area. It's important to study sustainability at minor land uses as well because sustainability can only be achieved through holistic development considering all land uses and parameters. Moreover, many organizations have come up with their green building rating systems based on building typology.

Many conferences and declarations were held to promote environmental educations at grass root level so that the seeds of sustainable living are implanted at the very beginning. So, the role of Universities become very important to bring out this change and is also highlighted in Talloires declaration. The subsequent declaration also gave emphasis not only on the sustainable education but also in policies making and physical development of universities. Further, Chang D.Y. argues that Educational Institutions are often not considered as a significant contributor to energy-intensive operations in India, which can be attributed to the low energy consumption per square unit of space in comparison to other commercial land uses. But, Tulsyan et al., [30] have shown that energy saving up to $18-20$ percent is still achievable in case of educational institutes while Rehman et al. [31] have come up to 40 percent savings in energy consumption in engineering institute. So there is still the possibility of energy saving in institutes despite being low energy consumption per square unit of space. For example, an energy audit of IIT Roorkee in the year 2010 shows that the energy consumption is $7.95 \mathrm{GW}$, which comes out to be approx. $20 \mathrm{kWh} / \mathrm{m} 2 /$ annum [32]. This energy consumption indicator seems less but looking at the magnitude of the energy consumption; a small sustainable measure can yield substantial energy saving. Moreover, the energy consumption in IIT Mumbai is three times the national average [33]. Guan et al. [34] argue that energy planning for University is gaining importance, but due to insufficient energy use data accumulation, the energy consumption pattern, characteristics in Universities is not well understood which is pretty much necessary for doing any energy planning from the demand side perspective. Moreover, educational campuses can act as role model for any surrounding community for implementation of new strategies and can as a catalyst for the sustainable development around the surrounding community areas.

\section{Conclusion}

Environmental sustainability which is one of the three pillars of sustainable development is addressed significantly in the various bureaucratic documents and declarations, conferences and green building rating systems across the globe. Even though it is expressed elaborately, it falls beside other pillars of sustainability, i.e., economic and social sustainability. The relative gain of the importance of environmental suitability in last two decade or so especially after the Brundtland Commission Report gave way to environmental sustainability equal importance to that of other two sustainability pillars if not more which is also clearly visible in the concerned shown by United Nations from time to time.

The global level declarations and conventions have highlighted the importance of sustainable development at the university level, and some of the universities are following them, and some of them have developed their own sustainability criteria's. Many of the Indian universities and institutes have come up with good solutions to achieve sustainability, but there is a long way to go as further exploration is needed in this regard. Study of the local sustainability aspects is also necessary as sustainability of educational campuses also depends on the locations in which they are located, and hence generalization of all the policies may not be ideal.

Sustainable development is an important aspect of human life and has a significant impact on the economy of the country. Energy efficiency is one of the most significant parts of the sustainable development framework, and most of the green rating systems have maximum criteria points under this head. Further, it is clear from the above review of literature that most of the universities in India have either not signed any of the major national or international declarations or have their long-term sustainability policy. Moreover, green rating systems may not guarantee environmental sustainability, as it is point based system and ambiguity is still possible despite having mandatory clauses. If sustainable development is to have a fundamental impact, this concept has to be made more elaborate, workable, practical, and free from politically driven motives in favor of intellectual clarity and objectivity.

\section{References}

[1]. K.C. Samir and W. Lutz, "The human core of the shared socioeconomic pathways: population scenarios by age, sex and level of education for all countries to 2100", Global Environmental Change, Vol. 42, (2017), pp. 181-192, https://doi.org/10.1016/j.gloenvcha.2014.06.004.

[2]. A.W. Drezner, "The new new world order", Foreign Affairs, Vol. 86, No. 2 (2007), pp. 34-36, available online: http://www.jstor.org/stable/20032282 (last visit: 10.11.17)

[3]. Talloires Declaration, 1990, available online: http://ulsf.org/wpcontent/uploads/2015/06/TD.pdf

[4]. K.N. Sharma, "Environment in Ancient India, Encyclopaedia of the History of Science, Technology, and Medicine in Non-Western Cultures, pp. 1-8. (2008), available online: http://doi.org/10.1007/978-94-007-3934-5 10320-1

[5]. S.V.S. Rana, Essentials of ecology and environmental science, PHI Learning Pvt. Ltd. (2013)

[6]. J. Brown, M.E. Hanson, D.M. Liverman, R.W. Merideth, "Global sustainability: toward definition", Environmental Management, Vol. 11, No. 6, (1987), pp. 713-719, http://doi.org/10.1007\%2FBF01867238.

[7]. R. Shearman, "The meaning and ethics of sustainability", Environmental Management (1990) 14: 1. https://doi.org/10.1007/BF02394014

[8]. https://en.oxforddictionaries.com/definition/sustainable assessed on 24th August 2017.

[9]. A.R. Trisoglio, "Sustainable development in a complex world", Ph.D. Thesis, University College London. PP.23-24, (1996).

[10]. S. Viederman, "Sustainable development: what is it and how do we get there?", Current History, Vol. 92, No. 573, (1993), pp.180-185, 
available

online:

https://search.proquest.com/openview/f68740b9f97a3a61c71ac3ec4 7dd2957/1 ?pq-origsite $=$ gscholar\&cbl=1816367 (last visit: 9.11 .17 )

[11]. H. Brooks, "The concepts of sustainable development and environmentally sound technology", ATAS Bulletin, Vol. 7, (1992), pp.19-24, available online: https://www.ecolex.org/details/literature/the-concepts-ofsustainable-development-and-environmentally-sound-technologyana-047747/

[12]. H. Meadows, D. Meadows, J. Randers and W. W. B. Iii, (1972) "Limits to Growth."

[13]. S.M. Lélé, "Sustainable development: a critical review", World Development, Vol. 19, No. 6, (1991), pp. 607-621, https://doi.org/10.1016/0305-750X(91)90197-P.

[14]. G.H. Brundtland, "Our Common Future", Report of the World Commission on Environment, New York, (1987), pp. 318,

[15]. N. Hanley, I. Moffatt, R. Faichney and M. Wilson, "Measuring sustainability: A time series of alternative indicators for Scotland", Ecological Economics, Vol. 28, No. 1, (1999), pp. 55-73, http://doi.org/10.1016/S0921-8009(98)00027-5

[16]. I. Moffatt, N. Hanley. "Modelling sustainable development systems dynamic and input-output approaches." Environmental modelling \& software 16, no. 6 (2001), PP.545-557.

[17]. R. Goodland and H. Daly, "Environmental sustainability: universal and non-negotiable", Ecological Applications, Vol. 6, No. 4, (1996), pp. 1002-1017, http://doi.org/10.2307/2269583.

[18]. http://data.worldbank.org/indicator/EG.USE.PCAP.KG.OE?locatio ns $=\mathrm{IN}$, assessed on 24th August 2017.

[19]. T. MNRE, GRIHA Manual, Volume 1: Introduction to Nationa Rating System-GRIHA, An Evaluation Tool to Help Design. (2010), PP.1, available online: http://www.grihaindia.org/files/Manual_VolI.pdf

[20]. C.C. Lee and C.P. Chang, "Energy consumption and economic growth in Asian economies: a more comprehensive analysis using panel data", Resource and Energy Economics, Vol. 30, No. 1 , (2008), pp. 50-65, https://doi.org/10.1016/j.reseneeco.2007.03.003.

[21]. K. Flint, "Institutional ecological footprint analysis: a case study of the University of Newcastle, Australia", International Journal of Sustainability in Higher Education, Vol. 2, No. 1, (2001), pp. 4862, http://doi.org/10.1108/1467630110380299.

[22]. http://mhrd.gov.in/university-and-higher-education, assessed on 24th August 2017.

[23]. United Nations Conference on the Human Environment, Stockholm, online available: http://www.undocuments.net/unchedec.htm

[24]. T.S.A. Wright, "Definitions and frameworks for environmental sustainability in higher education", Higher Education Policy, Vol. 15, No. 2, (2002), pp. 105-120, https://doi.org/10.1016/S09528733(02)00002-8.

[25]. C. Salinas-Meoni, (Salinas.iau@unesco.org). (2001, February 16). IAU-Kyoto Declaration Info. E-mail to Tarah Wright (tswright@ualberta.ca).

[26]. J. Walton, "Should monitoring be compulsory within voluntary environmental agreements?" Sustainable Development, 8(3), (2000), pp.146-154.

[27]. P. Dearden, \& B. Michell, "Environmental change and challenge: A Canadian perspective". Toronto: Oxford University Press. Jenstrrom, (1998).

[28]. W. Rees, M. Wackernagel, "Urban ecological footprints: why cities cannot be sustainable - and why they are a key to sustainability". Environmental impact assessment review. (1996) Jul 1;16(4-6):22348.

[29]. Cole, J. Raymond, "A Building Environmental Assessment Method for British Columbia”, Environmental Research Group, School of Architecture University of British Columbia, (2001).

[30]. A. Tulsyan, S. Dhaka, J. Mathur and J.V. Yadav, "Potential of energy savings through implementation of Energy Conservation Building Code in Jaipur city, India", Energy and Buildings, Vol. 58 (2013), pp. 123-130, https://doi.org/10.1016/j.enbuild.2012.11.015.

[31]. S.J. Rehman, "Energy Audit of Techno India Engineering College", Salt Lake Campus, (Doctoral dissertation). (2010)

[32]. Energy Audit Team, "ENERGY AUDIT OF IIT-ROORKEE CAMPUS" IIT-ROORKEE, (2010), available online: http://ahec.org.in/internship/ENERGY_AUDIT_report_of_IITR_ja n2010.pdf (Last Visit: 10.11.2017)

[33]. M. George, C. Abraham, V. Jose, S. Deshpande, "Energy Audit of IIT-Bombay Campus", Draft Final Report, Indian Institute of Technology-Bombay, http://doi.org/10.13140/RG.2.1.2406.8962.

[34]. J. Guan, N. Nord and S. Chen, "Energy planning of university campus building complex: Energy usage and coincidental analysis of individual buildings with a case study." Energy and Buildings 124 (2016): 99-111. https://doi.org/10.1016/j.enbuild.2016.04.051 